\title{
O EU E O OUTRO NA COMPOSIÇÃO POÉTICA DE UM JOVEM ESTUDANTE
}

\section{THE EXPRESSION OF THE SELF AND THE OTHER IN THE POETIC COMPOSITION PROCESS OF A YOUNG STUDENT}

\author{
Suely Corvacho $0^{130}$ \\ Cristina Lopomo Defendi ${ }^{131}$
}

\begin{abstract}
RESUMO: A partir da proposta de Bakhtin (1997), que concebe o enunciado como a unidade da língua, o que pressupōe um enunciador, situaçăo de enunciaçăo, valores expressivos, uma resposta a enunciados já ditos, uma projeçăo da compreensáo responsiva do outro, o artigo analisou um texto poético produzido por um aluno da quinta série/sexto ano de uma escola estadual de Săo Paulo, dirigido à măe, com os seguintes objetivos:(i) verificar como o contexto interferiu no enunciado; (ii) identificar as marcas de subjetividade do autor, comparando seu texto a outros nos quais se apoiou; (iii) levantar possíveis relaçôes entre marcas de subjetividade e discursos da vida cotidiana. Para identificar os recursos linguísticos e estilísticos absorvidos, cotejou-se o texto escolar e os que o aluno escolheu para se inspirar: um poema de um autor consagrado ("Para sempre", de Carlos Drummond de Andrade), um texto poético produzido por um professor de Português, e uma cantiga portuguesa. Nos três textos, há em comum a homenagem à máe. O resultado da análise aponta para uma escrita que busca o modelar, que se apropria de alguns recursos como forma de ter sua produçâo bem aceita e, quando se distancia dos "modelos", resgata uma visăo de mundo veiculada pela publicidade: um mundo harmonioso, um eu autocentrado e uma forma de seduçâo específica.
\end{abstract}

Palavras-chave: Recursos linguístico-estilísticos; Gêneros textuais; Análise textual; Intersubjetividade.

ABSTRACT: In Bakhtin 's view (1997), the concept of utterance is constructed between two socially organized persons. As a consequence, a unit of language is addressed to someone which is formed by a speaker and a receiver through the social interaction with a listener or an audience whose reaction integrates in advance. In anticipation of the other 's active responsive based on the interlocutor 's perspectives of the ideas of Mikhail Bakhtin and his circle, this paper aims to analyze a poetry written by a secondary school student enrolled in a public school of the state of Sâo Paulo. The poetic text is addressed to the student's mother and allow us to interpret three main

130 Professora Doutora aposentada do IFSP, campus São Paulo - sucorvacho@uol.com.br

131 Professora Doutora do IFSP, campus Săo Paulo - crislopomo@hotmail.com 
proposition for this investigation: (i) to verify how the context realize the utterance; (ii) to look for trace of the identity in the writing, establishing a comparison amongst the others authors that have supported the student 's poetry; (iii) to raise possible relations among subjectivity marks and discourse of the everyday life. One of the authors who inspired the student's poetry was the Brazilian poet, Carlos Drummond de Andrade, in his poetry "Para sempre". Moreover a poetry written by a Portuguese professor and a Portuguese song grounded a tribute to mother pointing out our assumption about bakhtinian perspectives on other 's active responsive. It is possible to present a preliminary result that shows a written "modulated" that search out other linguistics subsidies, such stylistic, to be properly accepted. It may motivate and encourage students to a kind of specific seduction around a harmonious world providing them to get into a self-centered perception.

Keywords: Linguistic-stylistic features; Textual genres; Textual analysis; Intersubjectivity.

\section{INTRODUÇÃO}

Em Questóes de estilística no ensino da língua, Bakhtin defende a necessidade da abordagem estilística para ajudar o aluno a criar uma linguagem própria. Embora o texto tenha sido escrito há mais de setenta anos e o autor inspire os documentos oficiais brasileiros, como os Parâmetros Curriculares Nacionais, poucas experiências, no Brasil, resolveram satisfatoriamente a integraçăo entre aspectos semânticos, sintáticos e estilísticos no ensino da língua materna.

O exame dos livros didáticos da quinta série/sexto ano do ensino fundamental permite perceber a separaçâo entre os vários aspectos. Ainda que as formas gramaticais sejam estudadas em relaçăo ao contexto semântico, raramente, as implicaçōes estilísticas das diferentes escolhas linguísticas săo exploradas. Quando ocorre, a abordagem estilística restringe-se à análise de textos literários objetivando o reconhecimento de figuras de linguagem, o que é insuficiente para que o aluno compreenda e incorpore a experiência em sua linguagem cotidiana. Sem a articulaçáo entre as diversas dimensóes da linguagem, o aluno năo recebe orientaçáo para desenvolver seu estilo próprio e, ano após ano, vai abandonando suas iniciativas em favor de fórmulas consagradas. O problema nâo é novo. Já nos anos quarenta, Bakhtin afirma que o processo escolar uniformiza a linguagem da criança: "Nessa linguagem infantil, embora de modo desajeitado, expressa-se a individualidade do autor; a linguagem ainda năo está despersonalizada" (BAKHTIN, 2013. p. 7).

No entanto, ao lado do processo de uniformizaçăo, o aluno do Ensino Fundamental resiste e, timidamente, incorpora e modifica outros textos na tentativa de construir sua subjetividade na linguagem. Acerca desse processo, pouco se sabe. Esforços pontuais, especialmente as investigaçōes em torno da Aquisiçâo da linguagem nas séries iniciais do Ensino Fundamental, têm iluminado alguns ângulos. É o caso do trabalho de Marina Célia Mendonça e Natalia Grecco (2014) que procuram entender a questâo do estilo. Essas pesquisas abrem perspectivas para a necessária e proveitosa integraçăo entre os vários aspectos, em especial, o estilístico no ensino da língua. 
A Estilística é uma antiga área de conhecimento que passou por diversas transformaçōes. Originariamente, stilus significava "instrumento pontiagudo usado pelos antigos para escrever sobre as tabuinhas enceradas", conforme consta em algumas obras de Cícero (século I a.C.); em Plínio, já aparece com a acepçâo de "maneira de escrever" (FARIA, 1988, p. 517). Como disciplina, a Estilística surge no século XX, substituindo a Retórica. Charles Bally desenvolve a Estilística da língua, estudando os "elementos afetivos, ativos, imaginativos e valorativos da linguagem", e Leo Spitzer, a Estilística literária, concebendo o "estilo como revelaçăo do homem" (MARTINS, 1989, pp. 10-11).

Outra importante contribuiçăo é a comunicaçăo de Roman Jakobson, "Linguística e poética", proferida em 1958 na Universidade de Indiana. Alegando falta de precisáo, Jakobson propóe a substituiçăo dos conceitos de Estilística e estilo para Poética e funçâo poética, cujo objeto da primeira é "esclarecer o que é que faz da mensagem verbal uma obra de arte" (MARTINS, 1989, p. 11); o da segunda, a preocupaçăo com a mensagem enquanto tal e sua organizaçâo interna. O estudo das funçôes de linguagem, entre as quais a poética, penetra o espaço escolar brasileiro nos anos setenta e permanece ainda hoje como um dos elementos formadores dos jovens estudantes. Entretanto, seu uso é restrito, adotado apenas para fins classificatórios.

A preocupaçăo de Jakobson tem como berço o Formalismo russo do início do século $\mathrm{XX}$, vertente crítica com a qual os componentes do Círculo bakhtiniano polemizam. As críticas sáo bastante exploradas no livro de Medviédev, 0 método formal nos estudos literários, porém o que nos interessa especificamente é o conceito de estilo. Conforme Beth Brait, para se apreender "a forma de ser da linguagem, que, sendo social, histórica, cultural, deixa entrever singularidades, particularidades, sempre afetadas, alteradas, impregnadas pelas relaçôes que as constituem", é necessário ler, ao menos, "O discurso na vida e na arte", Estética da criaçâo verbal, Marxismo e filosofia, Problemas da poética de Dostoiévski, Questóes de literatura e de estética: a teoria do romance, A cultura popular na Idade Média e no Renascimento: o contexto de François Rabelais". (BRAIT, 2013, p. 80). Para amparo teórico do artigo, restringiremos a leitura a três textos: "Os gêneros do discurso", "O discurso na vida e na arte" e Questōes de estilística no ensino da língua, todas atribuídas a Bakhtin e cujo teor permite o exame do estilo em textos do cotidiano escolar, objeto da análise.

Examinamos o estilo de alunos da $5^{\mathrm{a}}$ série $/ 6^{\circ}$ ano, como absorvem e modificam textos literários, construindo marcas da sua individualidade na linguagem. Para este artigo, dentre os vários alunos, escolheu-se aquele que reproduziu, mais de perto, as marcas dos "modelos", porque acreditamos ser possível identificar com maior clareza as incorporaçóes do texto alheio e as manifestaçóes da (inter)subjetividade. Para efeitos de apresentaçăo, explicitaremos nosso arcabouço teórico e, em seguida, a análise do poema produzido pelo aluno, dividida em três partes: a situaçăo extraverbal, as singularidades e os discursos incorporados pelo autor para criar suas marcas subjetivas.

\section{EXPLICITAÇÃO TEÓRICA}

O exame das marcas na linguagem do aluno exige a definiçăo de três conceitos básicos - enunciado, gênero do discurso e estilo - bem como suas implicaçóes no contexto escolar. 


\section{ENUNCIADO}

Bakhtin (2000) concebe que a unidade da língua é o enunciado (orais e escritos) concreto e único, proferido por integrantes de uma esfera da atividade humana. Pressupóe, pois, um enunciador, situaçăo de enunciaçăo, valores expressivos, uma resposta a enunciados já ditos, uma projeçăo da compreensăo responsiva do outro. Além disso, três elementos estâo envolvidos no enunciado - conteúdo temático, estilo e construçáo composicional -, que se fundem "indissoluvelmente no todo do enunciado, e todos eles săo marcados pela especificidade de uma esfera de comunicaçáo" (BAKHTIN, 2000, p. 279).

A esfera de comunicaçăo analisada é a escolar, especificamente, uma sequência didática de Português em que o professor procura ensinar o gênero poético, articulando-o ao momento social. $O$ aluno elaborará um texto com as marcas do poema dirigido à máe em razáo do "Dia das máes". O gênero náo é escolhido pelo enunciador, mas pelo professor, que tem o objetivo de transformar o aluno em um leitor mais assíduo de poemas e, para sensibilizá-lo, escolhe a estratégia de colocá-lo na condiçăo de produtor. Trata-se, portanto, de um enunciado produzido numa situaçăo de enunciaçăo bastante complexa, envolvendo dois interlocutores: o professor, autor da proposta e a măe do aluno, receptora do poema.

\section{GÊNEROS DO DISCURSO}

Para Bakhtin, os enunciados apresentam tipos relativamente estáveis em cada esfera de comunicaçăo, "sendo isso que denominamos gêneros do discurso." (BAKHTIN, 2000, p. 279). 0 texto analisado foi produzido na esfera de comunicaçấo escolar, cujos gêneros apresentam singularidades significativas. Segundo Schneuwly e Dolz, o gênero escolar é, ao mesmo tempo, instrumento de comunicaçăo e objeto de ensino-aprendizagem. Em virtude disso, o aluno está num espaço em que parte da prática de linguagem tem uma natureza ficcional: "o aluno encontra-se, necessariamente, num espaço de "como se", em que o gênero funda uma prática de linguagem que é, necessariamente, em parte, fictícia, uma vez que é instaurada com fins de aprendizagem" (SCHNEUWLY e DOLZ, 2011, p. 65).

Na situaçáo analisada, o professor tenta minimizar a dimensáo ficcional, esclarecendo que o texto năo seria objeto de avaliaçăo, mas de comunicaçăo, aspecto insuficiente para minimizar a interferência do contexto escolar sobre o texto.

Para compor seu texto, o aluno é exposto a poemas produzidos na esfera literária, cuja particularidade Bakhtin explora em "La palavra en la vida y la palavra en la poesía". O artístico representa "uma forma especial da interrelaçăo entre o criador e os receptores, relaçăo fixada em uma obra de arte". (VOLOSHINOV/BAKHTIN, 1997. p. 111) ${ }^{132}$. Para o autor, a comunicaçâo artística, fixada na obra de arte, é única e năo se reduz a outros tipos de comunicaçăo ideológica, como a política, a jurídica, a moral, entre outras; mas, ao mesmo tempo, năo está isolada: "participa da corrente única da vida social, reflete em si a base econômica comum e entra em interaçáo e intercâmbio de forças com outras formas de comunicaçăo." (VOLOSHINOV/BAKHTIN, 1997. p. 112).

132 Embora o texto-base seja em espanhol, apresentamos as citaçóes já traduzidas para o português. 
Por este motivo, há certa relaçăo entre o discurso cotidiano e literário, na medida em que os enunciados da fala da vida e das açóes cotidianas trazem em si as potencialidades da forma artística.

Como será visto, o texto produzido no seio escolar dista muito do gênero poético ainda que apresente versos, estrofes, entre outros elementos. Alheio aos rigores da esfera artística, o enunciador procura escrever um texto que agrade simultaneamente o professor e a măe. Os interlocutores, por sua vez, também năo esperam uma obra literária, mas uma comunicaçâo carregada de afeto. Tudo isso caracteriza o texto como um enunciado da vida e como tal deve ser analisado.

\section{ESTILO}

Em "La palavra en la vida y la palavra en la poesía", Bakhtin afirma que o discurso cotidiano está estreitamente ligado a fatores do contexto extraverbal e enumera os três fatores que o compóem: o horizonte espacial comum dos interlocutores; o conhecimento e a compreensăo comum da situaçăo por parte dos interlocutores; e sua avaliaçáo comum dessa situaçâo. O estudioso russo passa entâo a explorar a articulaçáo entre o horizonte extraverbal e o discurso verbal, afirmando que o enunciado concreto sempre une os participantes como coparticipantes:

sempre relaciona os participantes de uma situaçăo entre si como co-participantes que conhecem, compreendem e avaliam igualmente a situaçăo. Entâo, a enunciaçâo se apoia em sua relaçáo real e material a um mesmo fragmento da existência, e contribui para esta comunidade material com uma expressăo ideológica e um desenvolvimento ideológico posterior. (VOLOSHINOV/BAKHTIN, 1997, p. 115).

Essa observaçâo permite perceber que a situaçăo extraverbal nâo é a moldura do enunciado ou causa externa, mas parte integrante: "a situaçâo integra a enunciaçấo como a parte necessária de sua composiçâo semântica." (VOLOSHINOV/BAKHTIN, 1997, p. 115). Desta explicitaçấo, decorre a formulaçáo de que todo enunciado concreto compreende duas partes - a realizada com palavras e a presumida.

A parte presumida é apreendida na unidade material do mundo que entra no horizonte dos falantes e na unidade das condiçóes reais de vida que geram uma comunidade de julgamentos de valor: "Deste modo, todos os fenômenos que nos cercam estáo fundidos com os valores". (VOLOSHINOV/BAKHTIN, 1997, p. 117) Esses, por sua vez, determinam a própria seleçấo do material verbal e a forma do todo verbal, encontrando sua mais pura expressâo na entoaçaáo: "A entoaçăo estabelece um vínculo estreito entre a palavra e o contexto extraverbal: a entoaçăo viva parece conduzir a palavra para além das fronteiras verbais" (VOLOSHINOV/BAKHTIN, 1997, p. 118)

O autor acrescenta que a entoaçăo é orientada em duas direçôes distintas: "uma em relaçăo ao ouvinte como aliado ou testemunha, e outra em relaçăo ao objeto do enunciado, visto como se fosse um terceiro participante vivo, a quem a entoaçăo o repreende, acaricia, denigre ou engrandece". (VOLOSHINOV/BAKHTIN, 1997, p. 122) No caso analisado, como um dos interlocutores é o professor, que detém o poder na sala de aula, e como o outro interlocutor, a măe, que é também objeto do enunciado, o aluno adota um único tom nas duas direçóes. Toma os interlocutores como aliados e procura enaltecer o objeto. 
Nesta complexa arquitetura é que se insere a ideia de estilo, cuja natureza dialógica, segundo Bakhtin, impóe analisar o contexto extraverbal e os fatores que o compóem, a dimensâo realizada com palavras e a presumida, a entoaçăo, a cadeia de comunicaçấo na qual se insere:

Uma análise estilística que queira englobar todos os aspectos do estilo deve obrigatoriamente analisar o todo do enunciado e, obrigatoriamente, analisá-lo dentro da cadeia da comunicaçăo verbal de que o enunciado é apenas um inalienável (BAKHTIN, 2000. p. 326).

Para efeitos de apresentaçấo, a análise do texto do aluno foi dividida em três partes que correspondem aos objetivos perseguidos no artigo: i) verificar como o contexto interferiu no enunciado; (ii) identificar as marcas de subjetividade do autor, comparando seu texto a outros nos quais se apoiou; (iii) levantar possíveis relaçōes entre marcas de subjetividade e discursos da vida cotidiana.

\section{"DIA DAS MÃES" E A SITUAÇÃO EXTRAVERBAL}

O poema do aluno, objeto da análise, foi composto durante a primeira sequência didática aplicada pelo professor substituto. Em meados de abril de 2014, início da licença do docente titular, o professor substituto, estudante de Licenciatura dos anos iniciais, acompanhado por uma supervisora ligada à faculdade, iniciou o trabalho com quatro quintas séries/sextos anos em uma escola estadual de Sáo Paulo. A experiência, que durou até 11 de junho de 2014, início de recesso, conforme calendário especial em decorrência da Copa do Mundo da FIFA, teve como primeira atividade a composiçáo de um texto dirigido às măes dos alunos.

Escolheu-se o "Dia das Măes" porque a data ocupa espaço importante tanto na regiâo quanto no imaginário do público infantil. A escola, localizada em uma zona de comércio atacadista, impóe às crianças intenso contato com essa data, a segunda mais importante do comércio (após o Natal). Além disso, o imaginário infantil é estimulado por propagandas veiculadas na televisăo, nas estaçóes de rádio ou em cartazes de ruas. A publicidade foca nas crianças porque, manipulando o amor filial, consegue náo só vender os produtos como também formar novos consumidores. A linguagem publicitária, calcada na seduçăo e na construçáo de um modo de vida, atinge, cada vez mais, seu objetivo: transformar necessidades e desejos em mercadorias; no caso do "Dia das Máes", substituir o investimento afetivo pela compra de um objeto de consumo.

Com o objetivo de servir de contraponto a esse discurso, optou-se por reviver uma antiga prática: elaborar um texto que pudesse ser entregue no "Dia das Măes". A produçâo poderia ser dedicada a outra pessoa de escolha do aluno, uma vez que alguns nâo residem com a família. O gênero escolhido foi o poema e partia da leitura e análise de "Para sempre", composiçăo integrante de Liçāo de coisas de Carlos Drummond de Andrade.

É necessário que se esclareça que a sequência didática perseguia três objetivos diferentes: (i) contribuir para formaçấo como cidadăo, expondo o aluno a um discurso diferente do consumista; (ii) estimular a formaçăo de leitor, apresentando a dimensâo humanística da Literatura; (iii) aprimorar a produçáo textual, propiciando a experiência de o texto escrito ser veículo de afeto e espaço de reflexáo. A atividade foi realizada em três momentos: 
Primeiro momento - Aquecimento, com o objetivo de sensibilizar o educando para a atividade de leitura e expressáo oral. Primeiramente, os alunos ouviram (em CD) o poema dedicado às măes de Carlos Drummond de Andrade interpretado pela atriz Karin Rodrigues. Năo houve dificuldade de compreensăo e alguns se emocionaram. Depois, o professor e os alunos declamaram o poema e fizeram exercícios de expressâo oral.

Segundo momento -Análise, com o objetivo de trabalhar o poema em suas diferentes dimensōes: estética (gênero, estrutura do texto, funçăo do título, figuras de linguagem - eufemismo e repetiçăo); linguística (funçăo da oralidade no texto, tempo verbal, substantivos, uso do "porquê"); psicológica (o sentimento explorado no poema e sua relaçăo com a experiência individual), entre outras. Nas aulas seguintes, para examinar outros elementos presentes na composiçăo poética, nove poemas foram analisados. A análise foi realizada em sala de aula sob orientaçâo do professor.

$3^{\circ}$ momento - Composiçáo de poemas em homenagem à mâe (ou a outra pessoa). No dia previsto para elaboraçáo do texto, os alunos "desafiaram" o professor a compor um poema na lousa. Segundo o docente, ele inspirou-se na própria măe e, como, na faculdade, estava estudando a escola barroca, organizou o texto em torno da oposiçáo do claro e escuro, reservando o claro para a definiçấo da mâe e o escuro para situaçôes difíceis da vida. Quando concluiu, os alunos elogiaram e iniciaram seu texto.

Os poemas foram escritos em sala de aula, onde docente e discente conhecem, entendem e avaliam a situaçăo de maneira igual. No entanto, a relaçăo entre eles é hierárquica: o professor é autoridade com poder de voz e veto sobre a produçăo do aluno. Essa situaçăo está muito presente em "Dia das máes", texto do aluno escolhido para análise, pois, ainda que o professor tenha reforçado que o importante era o interlocutor - a mâe - percebe-se que o aluno ficou muito preso a "O fim", poema do professor.

O docente tentou neutralizar a relaçăo hierárquica, sublinhando que o texto nâo seria motivo de avaliaçăo escolar. Curiosamente, os alunos começaram a competir entre si para verificar "quem fazia o poema mais bonito", à exceçăo de alguns, como o aluno em questăo, que seguiram o poema do professor como "modelo", inclusive incorporando o início dos versos.

Outro elemento que pode ser associado ao contexto escolar é que "Dia das mâes" dialoga apenas com os poemas que estavam dirigidos à máe. Embora o professor tenha apresentado onze enunciados verbais, o aluno somente incorporou aspectos dos três relacionados ao tema, o que confirma a observaçăo bakhtiniana:

Este é um caso típico e importante: com muita frequência, a expressividade do nosso enunciado é determinada - às vezes nem tanto - náo só pelo teor do objeto do nosso enunciado, mas também pelos enunciados do outro sobre o mesmo tema aos quais respondemos, com os quais polemizamos; sâo estes últimos que determinam igualmente a insistência sobre certos pontos, a reiteraçăo, a escolha de expressóes mais contundentes (ou, pelo contrário, menos contundentes), o tom provocante (ou, pelo contrário, conciliatório), etc. A expressividade de um enunciado nunca pode ser compreendida e explicada até o fim se se levar em conta somente o teor do objeto do sentido" (BAKHTIN, 2000, pp. 316-7)

Portanto, percebe-se que "Dia das mâes" resulta da pressâo do contexto escolar em muitos aspectos: o gênero, a forma, o tema, o estilo; e mesmo quando o aluno cede à 
outra pressáo, a de agradar à măe, descola-se do poema do professor, recorre a uma cantiga apresentada em sala de aula.

\section{"DIA DAS MÃES" E SUAS SINGULARIDADES}

Para identificar as singularidades introduzidas pelo aluno, apresentamos inicialmente dois que parecem ter marcado presença na produçāo final do aluno: "Para sempre" e "O fim", de Carlos Drummond de Andrade e do professor, respectivamente. ${ }^{133}$

\begin{tabular}{|c|c|c|}
\hline $\begin{array}{l}\text { Para Sempre (Carlos } \\
\text { Drummond de Andrade) }\end{array}$ & O fim (professor) & Dia das mães (aluno) \\
\hline $\begin{array}{c}\text { Por que Deus permite } \\
\text { que as mães vão-se embora? } \\
\text { Mãe não tem limite, } \\
\text { é tempo sem hora, } \\
\text { luz que não apaga } \\
\text { quando sopra o vento } \\
\text { e chuva desaba, } \\
\text { veludo escondido } \\
\text { na pele enrugada, } \\
\text { água pura, ar puro, } \\
\text { puro pensamento. } \\
\text { Morrer acontece } \\
\text { com o que é breve e passa } \\
\text { sem deixar vestígio. } \\
\text { Mãe, na sua graça, } \\
\text { é eternidade. } \\
\text { Por que Deus se lembra } \\
\text { - mistério profundo - } \\
\text { de tirá-la um dia? } \\
\text { Fosse eu Rei do Mundo, } \\
\text { baixava uma lei: } \\
\text { Mãe não morre nunca, } \\
\text { mãe ficará sempre } \\
\text { junto de seu filho } \\
\text { e ele, velho embora, } \\
\text { será pequenino } \\
\text { feito grão de milho. }\end{array}$ & 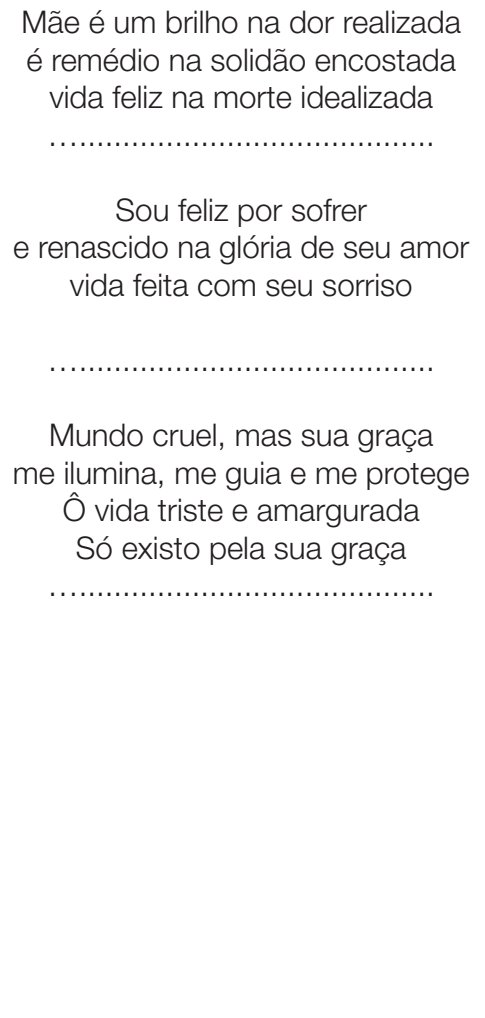 & $\begin{array}{l}\text { Mãe, é um brilho no meu coração } \\
\text { As vezes fico triste mas a sua } \\
\text { luz me ilumina } \\
\text { Sou feliz por que pra } \\
\text { Mim você é a melhor } \\
\text { você mãe é especial, só } \\
\text { existo pela sua graça e } \\
\text { pelo seu amor } \\
\text { x } \\
\text { Quando você cheira } \\
\text { uma rosa e eu sempre } \\
\text { penso uma rosa cheirando } \\
\text { outra rosa. }\end{array}$ \\
\hline
\end{tabular}

O cotejamento permite perceber que o aluno alterou o título, ignorou a relaçăo entre forma e conteúdo, diluiu as oposiçóes que estruturavam os poemas anteriores, optou por substituir metáforas por construçōes menos figurativas e retrabalhou a utopia presente no texto drummondiano.

O título - "Dia das mâes" - rompe com os escolhidos por Carlos Drummond e pelo professor. "Para sempre" remete à transitoriedade da vida e opta pela negaçâo, expressando, portanto, o desejo do eu lírico; já "O fim" mantém o mesmo sentido, mas sob o prisma da realidade, o que dá ao texto, desde o título, certo tom trágico. $\mathrm{O}$ aluno, por sua vez, evita a questăo da transitoriedade, preferindo

133 Todos os textos usados nas atividades encontram-se no Anexo. 
um título mais genérico - Dia das máes - que responde mais diretamente à data comemorativa.

Em "Para sempre", forma e conteúdo formam uma unidade indissolúvel. O autor cria um eu lírico, transpassado de dor pela perda, que, aos poucos, vai se transformando: sua condiçấo de adulto vai cedendo lugar à criança. As dores do eu lírico sâo cantadas em uma métrica popular, redondilha, linguagem coloquial, tudo, em suma, remete à simplicidade e à fragilidade da existência humana diante da morte.

Diferentemente do poema de Drummond, "O fim" persegue um modelo barroco em que as oposiçóes se exploram os contrastes da vida. Contudo năo é possível perceber a unidade entre forma e conteúdo nas três estrofes irregulares do poema. "Dia das máes" segue de perto esse poema e também náo articula forma e conteúdo. Apresenta quatro estrofes bem demarcadas năo só por espaço como também por um traço gráfico. As palavras iniciais das três primeiras estrofes repetem as do poema do professor, no entanto já na primeira estrofe rompe com o elemento estruturador dos poemas anteriores.

Tanto Drummond como o professor adotam o contraste para estruturar seus poemas. Em "Para sempre", a antítese é a figura recorrente para descrever a mâe, como: "Măe năo tem limite/ é tempo sem hora". Em "O fim", as oposiçōes ocupam também lugar privilegiado, como: "Sou feliz por sofrer". Em "Dia das mâes", a definiçâo da máe năo recorre a ideias contrastantes, mas aproxima-se de um silogismo: premissa maior - "Măe é brilho no meu coraçăo"; premissa menor: "às vezes fico triste (no meu coraçăo)"; conclusăo: "mas sua luz me ilumina (e termina minha tristeza)" Logo: "Măe é brilho (afasta a tristeza) no meu coraçăo".

O cotejamento permite perceber ainda que o aluno opta por uma linguagem mais concreta. O primeiro verso inicia-se tal como o do professor, "Máe é um brilho", no entanto o professor acrescenta "na dor realizada" enquanto o aluno prefere "no meu coraçăo". Opta, portanto, por uma construçâo mais comum e concreta. 0 verso seguinte - "Às vezes fico triste mas a sua/ luz me ilumina" apresenta uma releitura das imagens presentes nos poemas anteriores. Em "Para sempre", a măe é "luz que năo apaga/quando sopra vento/e chuva desaba,/". Em "Dia das mâes" as figuras (vento e chuva) săo "traduzidas" pelo correspondente - tristeza, o que denota que o aluno, compreendendo o sentido da metáfora, prefere a forma direta, até para mostrar sua compreensáo. Além disso, recupera o verso de "O fim", "Mundo cruel, mas sua graça/me ilumina, me guia e me protege", e substitui "sua graça" por "sua luz" numa imagem mais concreta do que a do professor.

A última estrofe apresenta uma situaçâo utópica cuja ideia parece beber no poema de Drummond e no fado "Măe", trabalhado na apostila de estilística.

\begin{tabular}{|c|c|}
\hline Mãe & Dia das mães (aluno) \\
\hline Eu vi minha mãe rezando & Quando você cheira \\
aos pés da virgem Maria, & uma rosa e eu sempre \\
era uma santa escutando & penso uma rosa cheirando \\
o que outra santa dizia. & outra rosa. \\
\hline
\end{tabular}

Para abrir o espaço utópico, a estrofe se inicia com uma expressâo temporal enquanto em Drummond tínhamos uma condicional "Fosse eu Rei do Mundo". 
Formulada por uma voz infantil em primeira pessoa do singular, com linguagem límpida, tom de insubordinaçâo, dicçáo marcada por diminutivo e comparativo coloquial ("pequenino", "feito"), o poema de Drummond denuncia o desejo da seguinte forma: "Fosse eu rei do mundo/baixava uma lei", o tempo será eterno e as máes náo morrerăo: "mâe ficará para sempre" apesar da passagem do tempo: "e ele, velho embora, / será pequenino/feito grâo de milho". Neste aspecto, vê-se novamente o trabalho do poeta ao retomar a consagrada expressâo de que os filhos nunca crescem para as mâes. Nesse espaço utópico, a inversăo, a alteraçăo da sintaxe e a construçâo do eu lírico infantil deixam claros que a mudança só pode ocorrer no plano imaginário, já que a morte é o limite irremediável.

Da complexidade da composiçấo de Drummond, percebe-se que fica apenas a tentativa de construir algo imaginário e lírico ao mesmo tempo em "Dia das máes". Para tanto, o aluno preenche sua utopia com reminiscências de chavôes populares, como: "uma flor para outra flor", "uma rosa para outra rosa", recriados à luz do "modelo" do fado: "era uma santa escutando o que a outra santa dizia", por "uma rosa cheirando outra rosa". Os demais elementos do fado năo entram na composiçăo, provavelmente porque o texto cruza a imagem da măe à da Virgem Maria, e a dimensâo religiosa está ausente do poema do aluno.

Vale ressaltar que no poema do aluno, a mesma técnica de entrecruzamento de imagens é usada, só que agora com "rosa" e "máe": "Quando você cheira/ uma rosa e eu sempre/ penso uma rosa cheirando/ outra rosa". A imagem da rosa associada à máe é bastante recorrente; ${ }^{134}$ a metáfora "măe é rosa" remete à beleza, à fragilidade, à feminilidade própria do imaginário construído acerca do papel social de mâe.

No poema "Duas santas" há, uma metáfora conceptual (Cf.: LAKOFF e JOHNSON, 1995): MÂE É SANTA. No texto do aluno, é mais uma metáfora linguística/estilística, que demonstra, porém, um princípio cognitivo: a compreensâo (e compressāo), ou seja, a projeçăo de dois campos semânticos que resulta na compreensăo de sua mesclagem.

\section{"DIA DAS MÃES" E OS OUTROS DISCURSOS}

Na última estrofe do poema criado pelo aluno, cuja tônica é a imagem apresentada (mâe-rosa), o EU se faz bem presente, na explicitude do sujeito e no verbo em primeira pessoa. Além disso, o verbo "pensar" é empregado no sentido de imaginar, como se o aluno projetasse num mundo aberto por essa construçấo "eu sempre penso" a imagem da mâe associada a uma rosa. No texto-base, a primeira pessoa funciona simplesmente para particularizar a măe que está sendo descrita: é a "minha máe": nos primeiros versos das duas primeiras estrofes "Eu vi minha măe rezando" e no primeiro verso da terceira estrofe "A minha mâe, ajoelhada". Na quarta estrofe, o EU só se manifesta na desinência verbal: vislumbrei. Na quinta estrofe, năo há manifestaçâo morfológica do eu. Ou seja, a recorrência e a importância dada ao EU no texto do aluno náo é meramente cópia dos textos motivadores.

134 Somente como ilustraçâo e sem contar a validade científica, em uma pesquisa no Google com a expressāo "mâe é rosa", houve um retorno de aproximadamente 18.200.000 resultados (0,27 segundos). 
A importância que o EU assume no poema criado merece atençâo especial, contudo, dados os limites do artigo, levantamos algumas hipóteses que deveráo ser aprofundadas futuramente. A primeira refere-se ao período psicológico do aprendiz. Conforme Wallon, a puberdade é o momento em que as outras pessoas săo menos importantes; a personalidade e o EU tomam o primeiro plano, retornando, assim, a atençăo sobre ele próprio.

A segunda hipótese está relacionada à influência do discurso televisivo (publicidade, telenovelas) na vida dos púberes. Como se analisou, tanto "Para sempre" quanto "O fim" privilegiam as oposiçóes, ainda que por motivos diferentes: no primeiro, é elemento estruturador; no segundo, reminiscência do barroco. No entanto, em "Dia das máes" percebe-se um esforço em atenuar as oposiçóes criando uma representaçăo do mundo mais harmoniosa, em que os conflitos parecem ausentes.

Náo só a visăo de mundo e o enfraquecimento das antíteses parecem remeter ao discurso midiático, mas também a forma de seduçáo em relaçăo ao outro. A segunda estrofe, embora se apresente em versos, trata-se de prosa: "sou feliz porque você é a melhor para mim" Aqui o jogo de seduçăo incorpora o discurso publicitário "ser a melhor pra mim" - a única. A terceira estrofe incorpora o verso do poema do professor, mas a adversativa se constrói de outra forma. Novamente o jogo de seduçăo incorpora o discurso publicitário, na fórmula cristalizada "você, mâe, é especial".

A terceira hipótese acerca da recorrência do eu aliado à visăo de um mundo harmonioso, sem contradiçóes e à forma como se dirige ao interlocutor pode, também, revelar traços da subjetividade contemporânea. De acordo com Joel Birman (2012), nas últimas décadas, a fragmentaçâo da subjetividade ocupa posiçâo fundamental no Ocidente. Esta fragmentaçăo é a matéria-prima por meio da qual outras modalidades de subjetivaçâo sâo forjadas, porém, em todas as modalidades, o eu encontra posiçâo privilegiada. Diferentemente da tradiçăo iniciada no século XVII, em que a subjetividade tinha como eixos as noçôes de interioridade e reflexăo sobre si mesma, agora o que se vê é o autocentramento em conjugaçăo com o valor da exterioridade. E acrescenta: "Com isso, a subjetividade assume uma configuraçăo decididamente estetizante, em que o olhar do outro no campo social e mediático passa a ocupar uma posiçâo estratégica em sua economia psíquica". (BIRMAN, 2012, p. 24).

Portanto, por meio da análise do estilo do aluno, isto é, com Beth Brait (2013, p. 80), "a forma de ser da linguagem, que, sendo social, histórica, cultural, deixa entrever singularidades, particularidades, sempre afetadas, alteradas, impregnadas pelas relaçôes que as constituem", podemos realizar inúmeras leituras cujas hipóteses apontam apenas algumas. No entanto, ainda que insuficientes, as hipóteses indicam a necessidade de continuar a pesquisa, talvez dirigida aos hábitos do aluno, para identificar outros fatores que contribuem na construçăo dessa singularidade. 


\section{CONSIDERAÇÕES FINAIS}

O objeto do artigo é o enunciado de um aluno da $5^{\mathrm{a}}$ série $/ 6^{\circ}$ ano de uma escola estadual cujo texto é dirigido à sua mâe. Para a análise estilística, tentou-se resgatar a cadeia da comunicaçáo verbal da qual o poema composto na escola era um elo. Percebeu-se que, embora o aluno tenha sido exposto a várias obras, ele apenas se apropria daquelas cujo tema é similar ao seu. Além disso, a sala de aula, em que o professor de Português procura que o aluno elabore um texto com as marcas do gênero poético dirigido à máe, introduz maior complexidade à situaçăo. $\mathrm{O}$ enunciado envolve dois interlocutores: o professor, autor da proposta, e a máe do aluno, receptora.

Compreendendo estilo, segundo a ótica bakhtiniana, o objetivo do artigo analisou três aspectos do enunciado do aluno: (i) como o contexto interfere; (ii) as marcas introduzidas pelo autor; (iii) os discursos incorporados pelo autor para criar suas marcas subjetivas. Com relaçâo ao primeiro objetivo, percebeu-se que o enunciado é quase totalmente definido pela esfera escolar. Desde o gênero, a forma, o início dos primeiros versos de cada estrofe, tudo remete aos poemas trabalhados em sala de aula, especialmente o produzido pelo professor e a cantiga popular portuguesa. A escolha provavelmente tenha ocorrido pela relaçăo hierárquica que se estabelece em sala de aula.

Com relaçăo ao segundo objetivo, após o cotejamento entre o poema do aluno e os que lhe serviram de "modelos", constata-se que as marcas de subjetividade podem ser sintetizadas em: atenuaçăo das antíteses e oposiçóes, supervalorizaçăo do eu e formas cristalizadas de seduzir o outro. A que se deve este fato, o artigo náo consegue responder. Contudo, algumas hipóteses foram lançadas para iniciar a futura pesquisa para identificar discursos do cotidiano que envolvem o jovem púbere justamente no momento em que está formando seus valores.

O artigo, portanto, ofereceu novos elementos para a avaliaçấo da atividade escolar e revelou alguns limites com relaçâo aos objetivos propostos. Ainda que a atividade escolar tenha contribuído para a formaçâo da cidadania, expondo o aluno a um discurso diferente do consumista, o que se notou foi que o discurso publicitário já penetrou níveis mais profundos de subjetivaçăo. Informaçăo importante para todos os que estâo envolvidos com a Educaçăo. 


\section{REFERÊNCIAS}

ANDRADE, C. Drummond. Liçăo de coisas. Săo Paulo: Companhia das letras, 2012.

BAKHTIN, Mikhail. Questōes de estilística no ensino da língua. Traduçáo: Sheila Grillo e Ekaterina Vólkova Américo. Săo Paulo: 34, 2013.

. Os gêneros do discurso.In: INFORMAR ORG. Estética da criaçáo verbal. Traduçấo: Maria Ermantina Galvăo G. Pereira. 3. ed. Săo Paulo: Martins Fontes, 2000.

BIRMAN, Joel. Mal-estar na atualidade: a psicanálise e as novas formas de subjetivaçáo. 9. ed. Rio de Janeiro: Civilizaçăo Brasileira, 2012.

BOSI, Viviana. Liçăo de coisas: "gerir o mundo no verso".In: ANDRADE, C. D. Liçăo de coisas. São Paulo: Companhia das letras, 2012.

BRAIT, Beth. (Org.). BAKHTIN: conceitos-chave. 5. ed. Sáo Paulo: Contexto, 2013.

FARIA, Ernesto. Dicionário Escolar Latino. 6. ed. Rio de Janeiro: FAE, 1988.

GRECCO, Natália; MENDONÇA, Marina C. Aquisiçăo da escrita e gêneros do discurso.In: DEL RÉ, Alessandra et al. Explorando o discurso da criança. Sáo Paulo: Contexto, 2014.

LAKOFF George e JOHNSON, Mark. Metáforas de la vida cotidiana. Traduçăo: José Antonio Millán e Susana Narotzky. 3. ed. Madrid: Cátedra, 1995.

MENDONÇA, Marina C. e GRECCO, Natália. Aquisiçâo da escrita e estilo.In: DEL RÉ, Alessandra et al. A linguagem da criança: um olhar bakhtiniano. Săo Paulo: Contexto, 2014.

SCHNEUWLY, B., DOLZ et al. Gêneros orais e escritos na escola. Traduçăo: Roxane Rojo e Glaís S. Cordeiro. 3. ed. Campinas: Mercado de Letras, 2011.

VOLOSHINOV, V. La palabra en la vida y la palabra en la poesía: hacia una poética sociológica. In: BAJTIN, Mijail M. Hacia una filosofía del acto ético: de los borradores y otros escritos. Traduçăo: Tatiana Bubnova. Barcelona/San Juan: Anthropos/Universidad de Puerto Rico, 1997, pp. 106-137.

VOLOSHINOV/BAKHTIN. 0 discurso na vida e discurso na arte. Traduçăo: C.Tezza e C. A. Faraco. Traduçăo para uso didático. Mimeografado. s.d. 


\section{ANEXOS:}

\section{Para sempre}

(Carlos Drummond de Andrade)

\section{Para Sempre}

Por que Deus permite

que as mâes vâo-se embora?

Mâe nâo tem limite,

é tempo sem hora,

luz que náo apaga

quando sopra o vento

e chuva desaba,

veludo escondido

na pele enrugada,

água pura, ar puro,

puro pensamento.

Morrer acontece

com o que é breve e passa

sem deixar vestígio.

Mâe, na sua graça,

é eternidade.

Por que Deus se lembra

-- mistério profundo --

de tirá-la um dia?

Fosse eu Rei do Mundo,

baixava uma lei:

Mâe nâo morre nunca,

mãe ficará sempre

junto de seu filho

e ele, velho embora,

será pequenino

feito grăo de milho.

O fim

(Informar nome do autor)

Mâe é um brilho na dor realizada é remédio na solidâo encostada vida feliz na morte idealizada

Sou feliz por sofrer e renascido na glória de seu amor vida feita com seu sorriso

Mundo cruel, mas sua graça me ilumina, me guia e me protege Ô vida triste e amargurada Só existo pela sua graça 
Mãe 135

(fado português, autoria desconhecida)

Eu vi minha mâe rezando aos pés da virgem Maria, era uma santa escutando o que outra santa dizia.

Eu vi minha máe rezando numa prece doce e pura; por todos estava orando, com grande amor e ternura!

A minha mãe, ajoelhada, aos pés da virgem Maria, parecia a madrugada ao romper de um novo dia! Como um sol que vem raiando vislumbrei com emoçâo: era uma santa escutando da outra santa, a oraçâo!

Unidas, no mesmo amor, a máe de Jesus, ouvia, com carinho e com fervor o que outra santa dizia! !36

\section{Dia das mâes}

(Informar nome do autor)

Mâe, é um brilho no meu coração

As vezes fico triste mas a sua

luz me ilumina

$$
x
$$

Sou feliz por que pra Mim vocêé a melhor $x$

O mundo é cruel mas você mâe é especial, só existo pela sua graça e pelo seu amor $X$

Quando você cheira uma rosa e eu sempre penso uma rosa cheirando outra rosa.

135 Fado. Autoria desconhecida.

136 Disponível em: 〈http://cancion-portuguesa.wikispaces.com/Eu+vi+minha+m\%C3\%A3e+rezando〉. Acesso em: 09 mar. 2012 